\title{
Cataloguing Arabic Manuscripts for the Project 'Katalogisierung der Orientalischen Handschriften in Deutschland'
}

\begin{abstract}
This article presents and assesses the outcomes of the project 'Katalogisierung der Orientalischen Handschriften in Deutschland' (KOHD) achieved in the 'Arabic manuscripts' section of the Verzeichnis der Orientalischen Handschriften in Deutschland (VOHD). The article describes and explains the (sometimes heterogeneous) method of cataloguing and thus serves as a guide to these volumes. Special attention is paid to the introductions and the numerous manuscriptological findings contained in them. The online database KOHD Digital, successor to the printed series, is also briefly presented, with particular attention to the question of sustainability.
\end{abstract}

\section{Introduction}

By the end of the year 2022, a mammoth German academic project, which began in 1958, will be finished. The name of the project in question is 'Katalogisierung der Orientalischen Handschriften in Deutschland' (KOHD). As its name implies, the aim of KOHD is to provide a union catalogue of Oriental manuscripts in German collections. In the following pages, I give an overview of the cataloguing activities in one of the larger language groups, the field of Arabic manuscripts. My aims are to present and assess the outcome of the project's book series, Verzeichnis der Orientalischen Handschriften in Deutschland (abbreviated VOHD), to describe and explain the rather heterogeneous method of cataloguing in the volumes that appeared between 1976 and 2020, and to compare what has been accomplished in the printed volumes with the successor to the printed series, the online database $K O H D$ Digital.

At the moment, a written work dedicated to the project's history does not exist. Nevertheless, ample material can be found in the introductions to the printed volumes (173 as of September 2020) as well as in the files (c. 185 in number) stored at the Staatsbibliothek zu Berlin - Preußischer Kulturbesitz (SBB), Orientabteilung. The following material outlines the background of the project. In November 1955, the Deutsche Forschungsgemeinschaft (DFG) issued a call for applications for the 'Priority Programmes' of 1956. After a significant delay, 
Dr Wolfgang Voigt (at that time of Westdeutsche Bibliothek Marburg) submitted a four-page application for the project 'Katalogisierung orientalischer Handschriften' in October 1957. The application was based on intensive consultation with libraries in East and West Germany, with the Deutsche Morgenländische Gesellschaft (DMG), and with numerous professors of Oriental studies. Voigt's justification for the cataloguing project amounts to fourteen lines; he points to complaints by German and international researchers that no printed catalogues had been compiled for Oriental manuscripts acquired after about 1900 by German libraries or museums. The DFG's first grant letter is dated 11 March 1958 (see Fig. 2) and provides funding for eight full-time collaborators who could begin their work in February 1958.

The librarian Wolfgang Voigt (1911-1982) initially managed the project. At the same time, he also became editor of the project's publication series VOHD, ${ }^{1}$ as would be the case for his successors too. Voigt held this position from 1958 until his death in 1982. ${ }^{2}$ His first two successors were the SBB librarians Dieter George (1935-1985, head of KOHD 1982-1985), ${ }^{3}$ and Hartmut-Ortwin Feistel (b. 1943, head of KOHD 1985-2013). Tilman Seidensticker, Professor of Arabic and Islamic Studies at the University of Jena and author of this article, has led the project since 2013.

There have been two major changes to the project since its founding. The first was a transition from DFG funding to the patronage of the Akademie der Wissenschaften zu Göttingen in 1990. The second change was in the medium of cataloguing. Since 2016, most of the results have been published in the online database KOHD Digital (more on this below). Nevertheless, all the catalogues which were planned and prepared prior to 2016 are still being published in print in the project's publication series VOHD. The number of collaborators, both fulltime and honorary, along with their individual Oriental language specialisations, also varied over time.

Voigt made one notable miscalculation in his report. According to his prediction, 'even in the case of the large holdings in Islamic and "Indian" manuscripts, the work will be completed, if possible, in $1963{ }^{\prime}{ }^{4}$ In reality, the work would be finished around sixty years later than Voigt had hoped. The delay was due to several factors, the most significant of which is that many libraries - not surprisingly - continued to acquire Oriental manuscripts after the project had

\footnotetext{
1 Voigt 1957/58, 68-69.

2 On Voigt, see Ernst Hammerschmidt's obituary (Hammerschmidt 1985).

3 On George, see Martin Kraatz's obituary (Kraatz 1987).

4 Voigt 1957/58, 69.
} 
begun. Furthermore, the first inventory listed around 14,000 Oriental manuscripts. ${ }^{5}$ This figure was later corrected to 'more than 40,000' and then to 'more than 70,000 '. ${ }^{6}$ The increase was due not only to further acquisitions, but also to more exact (i.e. larger) figures furnished by the libraries. From the beginning, one factor has counteracted this increase of material. Voluntary specialists from Germany and abroad, who were not funded by the project, helped out by preparing numerous volumes. For example, since 2014, eight volumes have appeared which relied on such external assistance, comprising 3,850 pages in total. $^{7}$

\section{The VOHD sections treating Arabic manuscripts}

Section (= sub-series) XVII Arabic manuscripts is specifically designated for descriptions of manuscripts in Arabic. For several reasons, other sections of the series also contain descriptions of Arabic manuscripts; these other sections shall be briefly mentioned before the main section and its specifics are presented in greater detail.

Ewald Wagner published a volume devoted to Islamic manuscripts from Ethiopia (XXIV, 2, 1997) in section XXIV African manuscripts. Descriptions of 139 Arabic works (from 88 manuscripts) are included. They stem from the archive of the Berlin-Brandenburgische Akademie der Wissenschaften (Nachlass Schlobies) and the author's collection, now in the possession of the Staatsbibliothek zu Berlin.

Section XXXVII Islamic manuscripts was created for smaller collections for which polyglot Arabic-Persian-Turkish experts could be found. Christian Arabic manuscripts were regularly included as well. Manfred Götz published a volume covering Nordrhein-Westfalen (XXXVII, 1, 1999), in particular the holdings of the Universitäts- und Landesbibliothek Bonn, the Universitäts- und Stadtbibliothek Köln, and the Kunstmuseum Düsseldorf. Within these 189 manuscripts, he found 104 works in the Arabic language. The next volume, written by Beate

5 Voigt 1957/58, 69.

6 The figure of 40,000 is reported by Voigt 1966, viii; that of 70,000 by Treue in Franke et al. $1976,3$.

7 V, 2 Erica Hunter and Mark Dickens 2014; XII, 8 Hartmut Walravens 2014; XVIIB, 11 Kathrin Müller 2014; XII, 7 Tsuneki Nishiwaki 2014; XII, 2 Renate Stephan 2014; XIII, 27 Dieter Maue 2015; XXXVII, 2 Manfred Götz 2015; II, 20 Siegfried Schmitt 2018; XVIIB, 14 Gregor Schoeler 2020. 
Wiesmüller (XXXVII, 4, 2005), could well have been included in section XVII. It describes, besides a small number of non-Arabic manuscripts, 340 Arabic manuscripts from the Max Freiherr von Oppenheim Stiftung, now in the care of the Oriental Institute at Cologne University. In his Thüringen volume (XXXVII, 5, 2001), Florian Sobieroj describes the collection of the Thüringer Universitätsund Landesbibliothek Jena, the Herzogin Anna Amalia Bibliothek Weimar, and a small remainder from the Forschungsbibliothek Gotha that was not described by Pertsch (1878-92). Within these holdings, there are 95 Arabic manuscripts with 139 Arabic works, as well as others with mixed Arabic-Turkish or ArabicPersian texts.

Section XLIII was created for a specific type of Arabic manuscript, namely, the Arabic manuscript fragments from the Coptic monasteries Dayr Abū Maqār and Dayr Abū Pšoi; these fragments are now kept in the Staats- und Universitätsbibliothek Carl von Ossietzky in Hamburg. For this section, Veronika Six authored an 1170-page volume - the most extensive in the whole VOHD series (XLIII, 1, 2017, bound in two parts).

Finally, there are volumes that cover a small number of Arabic components in multi-text manuscripts ${ }^{8}$ or in manuscripts with mixed Bohairic-Arabic content (XXI, 6 Ute Pietruschka and Ina Hegenbarth-Reichardt 2018). Mixed BohairicArabic manuscripts, as in the latter volume, are also described in VOHD XXI, 15 , but this fact is not evident from the catalogue titles.

The core section for manuscripts in Arabic is XVII Arabic manuscripts, divided into two subsections, A and B. The two volumes of subsection XVIIA, authored by Rudolf Sellheim (1928-2013), bear the subtitle Materialien zur arabischen Literaturgeschichte (XVIIA, 1-2, 1976 and 1987). Their contents exceed the expectations of a regular catalogue (see below, Section 4). The manuscripts he describes are an allegedly random selection (cf. VOHD XVIIA, 2, xi) from the holdings of the Staatsbibliothek zu Berlin - Preußischer Kulturbesitz, mainly from the shelf-mark group 'Ms. or. oct.'.

XVIIB is the core cataloguing subsection for manuscripts in Arabic. In this subsection, fourteen volumes were published between 1976 and 2020. Over roughly 7,300 pages, 4,318 Arabic manuscripts from the following libraries are described:

- Staatsbibliothek zu Berlin - Preußischer Kulturbesitz: XVIIB, 1: Ewald Wagner 1976 (362 MSS); XVIIB, 2: Gregor Schoeler 1990 (104 MSS); XVIIB, 3: Rosemarie Quiring-Zoche 1994 (199 MSS); XVIIB, 5: eadem 2000 (335 MSS); XVIIB, 6: eadem 2006 (311 MSS); XVIIB, 7: eadem (with Beate Wiesmüller)

8 XIII, 3 Hanna Sohrweide 1974; XIV, 2 Soheila Divshali and Paul Luft 1980. 
2015 (243 MSS); XVIIB, 13: eadem 2019 (724 MSS); XVIIB, 14: Gregor Schoeler 2020 (263 MSS). The work on this library's holdings is still in progress, with new descriptions appearing in KOHD Digital.

- $\quad$ Bayerische Staatsbibliothek München (BSB): XVIIB, 8: Florian Sobieroj 2007 (275 MSS); XVIIB, 9: idem 2010 (330 MSS); XVIIB, 10: Kathrin Müller 2010 (310 MSS); XVIIB, 11: eadem 2014 (170 MSS); XVIIB, 12: Florian Sobieroj 2018 (759 MSS). This library's formerly uncatalogued holdings ${ }^{9}$ are now all catalogued in the aforementioned volumes.

- Niedersächsische Staats- und Universitätsbibliothek Göttingen: XVIIB, 4: Tilman Seidensticker 2005 (44 MSS). Together with the large remainder of around 620 manuscripts, described by Florian Sobieroj in KOHD Digital, the formerly uncatalogued holdings of this library ${ }^{10}$ have been catalogued in their totality as part of the KOHD project.

The uncatalogued Arabic holdings of the Staats- und Universitätsbibliothek Hamburg $^{11}$ (besides the Christian Arabic fragments catalogued by Veronika Six; see above): 62 manuscripts, have been catalogued by Frederike-Wiebke Daub in KOHD Digital.

In the future, smaller collections of uncatalogued Arabic manuscripts from some libraries, such as the Universitätsbibiothek Tübingen, will be included in KOHD Digital, if there is capacity until the end of the project in 2022.

It was decided at the beginning of the project that each volume would be arranged systematically; 'for scientific reasons and in the users' best interest'. ${ }^{12}$ According to the rules of orthodox codicology, this is a mistake. In the case of multi-text manuscripts, it has been asserted that the codicological connexion between components is torn apart through systematic arrangement. This allegation, however, does not hold, since the codicological information of all multitext manuscripts is given at the beginning of the description of the first part. Immediately after the description of the first part, there is a short list that lets the user know which other parts follow and where they can be found in the catalogue. In this way, it is possible to change from a systematic arrangement to an alternative codicological arrangement without losing information.

Nevertheless, in some cases, arrangement according to ascending shelf marks was preferred. In the case of XVIIB, 4 (Göttingen, Seidensticker): where

9 That is, the manuscripts not catalogued in Aumer 1866.

10 That is, the manuscripts not catalogued in Meyer 1894.

11 That is, the manuscripts not catalogued in Brockelmann 1908.

12 Voigt 1957/58, 71. 
just 44 manuscripts with 80 works are contained in one volume, an arrangement according to content seems to be of little use. In the volumes XVIIB 8 and 9 (BSB), Florian Sobieroj has also followed an arrangement according to shelf marks. In his first volume, XVIIB, 8 , this arrangement seems to be particularly justified because it allowed a collection of Yemenite manuscripts bought from Eduard Glaser to be kept intact. In XVIIB, 14, Schoeler catalogued the Arabic parts of the format-related shelf-mark group 'Ms. or. fol.' of the SBB, and here too, an arrangement according to numerus currens seems to be more appropriate.

The sequence in which the collections of individual libraries were catalogued differs greatly. In the case of the Bayerische Staatsbibliothek, two experts, Sobieroj and Müller, worked simultaneously. They decided to approach the job like workers digging a tunnel from both ends. The Munich volumes XVIIB, 8 to 12 cover the shelf marks Cod. arab. 1058 to Cod. arab. 2820 in the approximate sequence $\mathrm{A}, \mathrm{B}, \mathrm{E}, \mathrm{D}$, and C. Things were more complicated in the case of the Staatsbibliothek zu Berlin, where four people were involved in cataloguing (Sellheim, Wagner, Schoeler, Quiring-Zoche). The shelf marks here are more complicated, since the Arabic collections are just a smaller share of four shelf-mark groups ('Ms. or. fol.', 'Ms. or. quart.', 'Ms. or. oct.', 'Hs. or.' [after 1945]). In two cases the authors were allowed to make their own choice from the shelves (XOHD XVIIA, 1-2, Sellheim; XVIIB, 2, Schoeler). This latitude makes it even more important than in the case of the Bayerische Staatsbibliothek to provide a general index for all the volumes. It was decided that this index should not be a printed index but rather be included in the project's database.

\section{The database KOHD Digital}

When the final KOHD phase (2016-2022) was planned, it soon became clear that much tighter cataloguing would be necessary. The numbers of uncatalogued manuscripts amounted to 1,400 Old Turkic, 1,230 Persian, 1,850 Sanskrit, and 3,300 Tibetan manuscripts. In the case of Arabic, there was a remainder of about 3,000 uncatalogued manuscripts. Online cataloguing was seen to be the best medium; printed volumes were considered an exception from then on. 
The design for the database ${ }^{13}$ did not need to be reinvented; rather, the project could build upon a database developed in a DFG-funded project (Verena Klemm, Leipzig University) that was intended for the Arabic, Persian, and Turkish manuscripts of Leipzig University Library. ${ }^{14}$ The data model for that database was largely built upon KOHD's description scheme. Between 2016 and 2019, the KOHD Digital model was gradually adapted to fit other language groups included in the KOHD project. ${ }^{15}$

This step uncovered huge differences between the manuscript cultures, an insight that had previously been hidden by the numerous sections and subsections in the VOHD series. Nevertheless, it proved possible to create a data model that was appropriate for all language groups and subgroups.

The final data model allows almost everything mentioned in the printed catalogues to be included. On the other hand, the approaching end of funding made it necessary to confine the work to the following elementary data:

1. Shelf mark

2. Possessing institution

3. Author

4. Biographical data

5. Author: bibliographical reference

6. Work title

7. Incipit in original script

8. Subject matter ${ }^{16}$

9. Number of folios

10. Measurement of folios/text areas

11. Number of lines

12. Copyist

13. Date of writing

14. Place of writing

13 In fact, the project had to design a second database because the specifics of the Coptic literary papyri catalogued in the Berlin workgroup 'Coptic manuscripts' demand a special treatment. Descriptions of the papyri, parchments, paper manuscripts, and ostraca are recorded in the database KOHD Coptica <https://coptica.kohd.adw-goe.de> (accessed on 22 April 2021, as all the other links quoted in this article).

$14<$ https://www.islamic-manuscripts.net/content/index.xml .

15 Both KOHD Digital and its Leipzig precursor are, on the level of data processing, much obliged to Jens Kupferschmidt (Computing Centre of Leipzig University).

16 To develop a universal thesaurus for subject matter that is applicable to all language groups seems to be an almost insuperable task. Therefore, the present subject-matter taxonomy is quite rough. 
15. Completeness

16. Reference to further copies

17. Glosses

18. Remarks

In practice, additional information can be given, and not only in the final 'remarks' field. If, for example, the cataloguing expert is able to easily identify a special type of script or the specific content, he or she can include this information in a data field specifically provided for this sort of metadata, and this field will then be visible to the users; if empty, it will not be visible.

Online databases have marked benefits, primarily instant worldwide accessibility and the possibility to correct mistakes and to add information retrospectively. On the other hand, their sustainability is limited in comparison to printed volumes, even beyond the question of data backup. A comparison with smartphones is revealing. Smartphones are technical marvels when they are released; their memory capacity and processing power massively dwarf that of the models they replace. Nevertheless, they all fail and turn into high-tech trash within ten years. It is the same with databases. The rapid changes in hardware, operating systems, and other software prohibit any predictions about whether a database will be (safely) usable even just a decade after the project's completion.

In the case of KOHD Digital, a way towards sustainability was found, based on the assumption that the possessing libraries are, in the long term, better able to provide data sustainability than anybody else, including the Göttingen Academy of Sciences and Humanities. Among German libraries, the Staatsbibliothek $\mathrm{zu}$ Berlin is the greatest with respect to its collection of Oriental manuscripts, and this library has accepted its share of responsibility in a highly constructive manner. A major DFG grant will allow the SBB to establish, from 2020 to 2023, a digital union catalogue that will provide fundamental metadata of Oriental manuscripts stored in almost all German libraries. The project was designed by Christoph Rauch, head librarian of the Oriental Department, who plans to start this work by focussing on manuscripts in Arabic script. A second project phase (2023-2025) may ensure that data from South Asian and Turfan manuscripts can be included as well. Data from printed catalogues published prior to or outside the VOHD series, as well as data from the VOHD series and from KOHD Digital, will be contained on this platform, Orient-Digital. (Meanwhile, the problem of 
sustainability for databases of recent decades has been identified on the level of the DFG as an important general task. ${ }^{17}$ )

\section{The method of cataloguing}

Before work started, Wolfgang Voigt published a detailed cataloguing scheme that was mandatory for all language groups..$^{18} \mathrm{~A}$ number of experts had deliberated on it during the $24^{\text {th }}$ International Congress of Orientalists in Munich in 1957. ${ }^{19}$ This scheme tended to be rather exhaustive but at the same time it restricted some type of information, which was allowed only in special cases (such as precious bindings, rare writing support, incomplete or incorrect foliation, etc.). When in 1976 the first two Arabic volumes were published (VOHD XVIIA, 1 Sellheim; XVIIB, 1 Wagner), a strange disagreement about the appropriateness of the scheme as applied to Arabic manuscripts became obvious. While Wagner stuck to Voigt's instructions and thus set standards for future XVIIB volumes, Sellheim denied that catalogues such as Wagner's were a meaningful enterprise. ${ }^{20}$ Short handlists, Sellheim argued, were senseless because for that purpose one could simply print the libraries' accession books. ${ }^{21}$ On the other hand, more detailed descriptions were hardly reasonable in Sellheim's eyes, because, as he wrote, the majority of manuscripts contain books or treatises that had been presented in previous catalogues or that have even been printed.

What Sellheim deemed desirable was to advance research in cataloguing, by ample reference to secondary or primary literature. The final aim of his work was nevertheless nothing more than to heap up material, in his words, '... daß sich folglich die Katalogisierung zu einer originären, aktuellen und anregenden Materialsammlung ausweitet'. ${ }^{22}$ In his two volumes, this interpretation of the

17 The initiative National Research Data Infrastructure (German abbreviation: NFDI) will, according to a letter of intent from 2020, try to preserve the ruins of as many former database as possible; cf. <https://www.dfg.de/en/research_funding/programmes/nfdi/index.html>.

18 Voigt 1957/58, 72-75.

19 George 1983, 159.

20 VOHD XVIIA 1, xvi-xvii. The principal thoughts of Sellheim's introduction had already been published two years earlier in a programmatic article bearing the title 'The Cataloguing of Arabic Manuscripts as a Literary Problem' (Sellheim 1974).

21 In recent decades it has become clear that in countless cases the accession books are unreliable.

22 VOHD XVIIA, 1, xvii. 
task brought forth graphic tables with transmitter chains, genealogical trees of authors, scribes, commentators, and former owners, stemmata of commentaries and glosses, and much more. These scholarly digressions are highly valuable for special aspects of Arabic literature and its transmission, but they are decidedly not what one would look for in a manuscript catalogue. Any ambition to make the masses of Arabic manuscripts accessible to the scholarly public demands more pragmatism than Sellheim was willing to allow.

Being committed to Voigt's scheme and, of course, Wagner's paradigmatic volume XVIIB, 1, the remaining thirteen volumes of the Arabic XVIIB section exhibit diversity in detail. To some extent, the authors were free to pay particular attention to aspects they regarded as especially important. From about 2010, all participants were aware of the project's approaching phase-out. Nothing can illustrate this change better than Rosemarie Quiring-Zoche's two volumes VOHD XVIIB, 7 and 13, both devoted to manuscripts from the SBB and compiled more or less simultaneously. In this case, the project's obligation to make sufficient progress resulted in a bipartite course of action. Quiring-Zoche decided, based on decades of experience, which manuscripts merited a long description (in VOHD XVIIB, 7). The remaining manuscripts were catalogued in a short format that was, up to that point, unusual (in VOHD XVIIB, 13), taking Rudolf Mach's Catalogue of Arabic manuscripts (Yahuda section) in the Garrett Collection, Princeton University Library (Princeton 1977) as a model. As Fig. 1 shows, for each work (a) its title, (b) the author, (c) his dates, including references, and (d) the incipit ${ }^{23}$ are given. For the manuscripts (six in that example), only (e) shelf mark, (f) number of folios, (g) number of lines, (h) text-area measurement, (i) name of the scribe, and, if known, (j) the place and date of writing are given.

In this way, each manuscript is described in no more than one or two lines. By contrast, in her other volume, XVIIB, 7, Quiring-Zoche devotes about one page to each work, and in some instances even more (for example, three and a half pages in the case of no. 71, pp. 60-64). Although the resemblance of volume 13 to a handlist is exceptional in the XVIIB section, the format did allow a forward leap of 724 manuscripts in describing the SBB's Arabic holdings within a short time.

23 It is inevitable that in this way the incipit is a standardized version; in other volumes the actual incipits, with their mistakes and deviations, are given. 


\section{b. Die Lehre von Muhammad dem Propheten}

232 K. ašššifä fi taci rîf huqūuq al-Muștafä

'Iyāọ ibn Mũsã AL-YAHȘUBI AL-QĀḌI 'TYĀḌ.

St. 544/1149; GAL2 1/455-6 S 1/630-2; KAHफ̣̂̄LA 8/16-7; ZIRIKLI 5/99; EI² 4/289-90; TDVIA 24/116-8. اللَّهَ ... الحمد لشه المنفرد باسمه ... امَا بعد انثرق الله قلبى وقلبك بانوار اليقين ...

1.: Hs. or. $5580: 314$ Bl. $7,5 \times 14,5 \mathrm{~cm} .19 \mathrm{Zl}$.

2.: Hs. or. $5581: 247$ Bl. $8 \times 15$ cm. 21 Zl. Ahmad Hațîb-zāda. 1. D̄a l-Hiǧğa 1213/6. Mai 1799. Einzelne Glossen.

3.: Hs. or. $5720: 299$ Bl. 7x14,5 cm. 19 Zl. Ismã Ṫl Dihnī ibn Muștafă, Schüler von Šaih Šăkir. Mi. im Rabí II 1251/ Juli-Aug. 1835.

4.: Hs. or. $6031: 332$ Bl. $6,5 \times 13,5$ cm. 17 Zl. 'Uțmān ibn Sulaimān ibn 'Uṭmān ibn 'Umar. Madrasat Hasan Păšă zu Konstantinopel, Fr., 18. Ǧumādã II 1280/Mo. (!), 30. Nov. 1863. Interlinear- und Randglossen.

5.: Hs. or. $6038: 206$ Bl. 8,5x16 cm. 23 Zl. Ibrāhīm ibn Husain ibn Ahmad al-Yãnyawĩ Qara Šăhīn-zāda. İzdin, 26. Rabiri II 1207/11. Dez. 1792.

6.: Hs. or. 8382: Bl. 2b-108a. 11,5-12,5x21 cm. 22 Zl. Mitte (nisf, 15.) Šawwal 709 (?)/18. März 1310 (?). (Nur 1. qism.)

(GAL ${ }^{2} 1 / 455,1$ S 1/630; QZ 3 Nr. 180-1; KARABULUT Nr. 6247,10.)

Fig. 1: Cut-out from VOHD XVIIB, 13, 56, showing the entry for a famous work on the prophet Muhammad from the sixth century AH (twelfth century $\mathrm{CE}$ ). Six copies are listed in a total of nine lines.

\section{The introductions}

Catalogues, which describe manuscripts one by one, cannot be properly used without indexes. The basic indexes include those referring to titles (in Arabic script and in transliteration), authors, scribes, and dated manuscripts. In addition, (a) places and buildings and (b) things (Sachen), terms, and groups of persons (XVIIB, 3, 5-12) can be made accessible by providing separate indexes. When it seemed appropriate, indexes of illuminated, illustrated, or otherwise particularly ornamented manuscripts were given (XVIIB, 2, 8-9). Further indexes of single collections or provenance (Yemenite, Maghribī) are provided in two volumes (XVIIB, 1 and 7). Nevertheless it is the introductions that are the most important place for presenting observations of a more general character. They contain a wealth of information, some aspects of which are presented in the list below.

- Although the indexes of dated manuscripts are an important and obligatory guide to the age of the manuscript in question, most introductions supply additional information on this subject, as well as tables showing the distribution of the volume's manuscripts according to century.

- Manuscripts containing unique, rare, or (in some sense) important texts are treated in detail, as are autographs or copies closely related to them. These paragraphs are particularly important to philologists. 
- When components of separate collections are contained in the catalogued manuscript groups, the background of these collections is covered. Ewald Wagner has given an overview of the collection of Rushayd Daḥdāh (XVIIB, 1, xvi-xvii); Rosemarie Quiring-Zoche has sketched the characteristics of the so-called Rescher collection, which mainly stems from the medrese milieu in Turkey and in the Balkans under Ottoman rule (XVIIB, 3, xii-xiii). ${ }^{24}$ The Bayerische Staatsbibliothek München owns 154 manuscripts from Yemen, acquired from Eduard Glaser. In a separate part of his introduction to XVIIB, 8 (pp. xxi-xxxviii), Sobieroj discusses these holdings, including their background, content, specifics, etc. A group of 26 manuscripts from the SBB, shelf-mark group 'Hs. or.', also originates from Yemen; their specifics are described by Quiring-Zoche in XVIIB, 7 (pp. xiii-xvi). ${ }^{25}$ Arabic manuscripts from the Maghreb are easily identified by their specific script. In XVIIB, 7, a separate section of the introduction is devoted to the $15 \mathrm{Ma}$ ghribi codices, especially their thematic range, described in that volume by Quiring-Zoche (pp.xvi-xviii). A very special type of provenance, quite common in the older holdings of German libraries, is the Türkenbeute, that is, spoils from the wars between European powers and the Ottoman Empire. ${ }^{26}$ In his Thüringen volume (XXXVII, 5), Sobieroj studied the collections that were acquired in this way and are kept at the libraries in Jena and Weimar (xiii-xiv). A shorter section of the introduction to XVIIB, 7, by Quiring-Zoche, is devoted to the same type of collection held by the SBB (p. xix).

- Closely related to the question of collections and provenance is the matter of former (particularly Oriental) ownership. In the introductions to volumes XVIIB, 3, 5-8, and 12, the former owners are discussed. In XVIIB, 3, QuiringZoche analyses their professions (p. xx). In XVIIB, 6, xiii-xiv, she presents the chain of owners as preserved by notes in the $1170 \mathrm{AH} / 1756-7$ CE copy of an Arabic dictionary. It was copied in Baghdad, purchased by a Damascene Christian monk, later sold to Shiraz, and finally came into the possession of a family member of the Iranian ruler Nāṣir al-Dīn (reigned 1264-1313 AH / $1848-1896$ CE) (pp. xii-xiii).

24 Quiring-Zoche's cataloguing work on the Rescher collection led her to author an article on Arabic literature in the Ottoman Empire; see Quiring-Zoche 1989.

25 For further studies specifically devoted to Yemenite manuscripts, see Quiring-Zoche's volume XVIIB, 7 , xiii, n. 2.

26 On the Türkenbeute, see Seidensticker 2017, 78-80. 
- The scribes have been a topic of interest in several introductions (XVIIB, 3, $8-9,12)$. Quiring-Zoche has written about their professions (XVIIB, 3, xx); Sobieroj presents important results concerning their mode of working, especially the time it took to copy manuscripts (XVIIB, 8, xxx-xxxi; 9, xviiixix). In XVIIB, 12, xxv-xxvi, Sobieroj deals with manuscripts that were written for the scribes' own use.

- Art historians might be interested in illuminated and illustrated manuscripts or those written by calligraphers. Beyond the aforementioned indexes, some introductions devote special attention to such holdings, including Schoeler's volume XVIIB, 2, xvii; Sobieroj's volumes XVIIB, 8, xviii and XVIIB, 9, xvii; Schoeler's volume XVIIB, 14, xvi-xvii; and Quiring-Zoche's volume XVIIB, $7, \mathrm{xix}-\mathrm{xx}$. The bindings are given special attention in the last-mentioned volume, pp. xx-xxii, as well as in Müller's volume XVIIB, 11, xxii-xxiii.

Notwithstanding the increasing time pressure, the authors were able to pay due attention to detail. In this way, the introductions yield an increase of manuscriptological knowledge in many instances. For example, in XVIIB, 8, Florian Sobieroj was able to present a formerly unknown, specifically Yemenite Arabic term, qașāssa, which obviously denotes some sort of collation (p.xxv). On the doublures of two Yemenite manuscripts, he also detected notes about marriages (p. xxxvii, n. 55). While the use of Arabic manuscripts as a family register is, generally speaking, a well-known practice, any mention of spouses was previously unknown. Some years later, Rosemarie Quiring-Zoche announced a similar discovery in another Yemenite manuscript (XVIIB, 7, xv). The XVIIB volumes do not pay particular attention to watermarks, but Kathrin Müller decided to do so in her two volumes XVIIB, 10 and 11 (and provided indexes for them). While it was previously known that in Venetian paper the three-crescents watermark (tre lune) began to dominate by the second half of the eleventh century AH (seventeenth century CE), in her introduction to XVIIB, 10 (p. 23) Müller draws attention to tre lune watermarks in a manuscript written in $1035 \mathrm{AH} / 1626 \mathrm{CE}$.

\section{Conclusion}

That catalogues published over a span of forty-five years by several authors differ in many respects is no surprise. The background for these differences given in this article demonstrates that, for several reasons, there is not just one adequate or correct method of cataloguing. The wealth of information to be 
found in many of the different volumes' introductions shows that one type of information will be lost during the transition from print publishing to databases: even though the introductions comment on sometimes random selections of manuscripts, observations about collections and groups of manuscripts, made by people with intimate knowledge of these selections, are rarely accomodated in databases. It is hoped that the cataloguer's focus on manuscript groups and the commonalities within these groups will somehow survive the change of media.

\section{Acknowledgements}

My cordial thanks to Christoph Rauch (Staatsbibliothek zu Berlin) for his help, particularly for providing access to the project files kept by the Orientabteilung, as well as to Beate Wiesmüller (KOHD Hamburg), Florian Sobieroj (KOHD Jena), and Gregor Schoeler (Basel) for their valuable comments on a draft version of this article.

\section{Abbreviations}

Verzeichnis der Orientalischen Handschriften in Deutschland (see below; all references to the VOHD volumes can be checked on the project's website: <https://adw-goe.de/forschung/forschungsprojekte-akademienprogramm/ kohd/publikations-serie/>.)

\section{References}

Aumer, Joseph (1866), Die arabischen Handschriften der K. Hof- und Staatsbibliothek in München, Munich: Palm'sche Hofbuchhandlung.

Brockelmann, Carl (1908), Katalog der orientalischen Handschriften der Staats- und Universitätsbibliothek zu Hamburg. Die arabischen, persischen ... Handschriften, Hamburg: Meissner.

Franke, Herbert, Walther Heissig and Wolfgang Treue (eds) (1976), Folia rara: Wolfgang Voigt LXV. diem natalem celebranti ab amicis et catalogorum codicum orientalium conscribendorum collegis dedicata (VOHD, Supplement vol. 19), Wiesbaden: Franz Steiner.

George, Dieter (1983), '25 Jahre Katalogisierung der Orientalischen Handschriften in Deutschland', Mitteilungen der Staatsbibliothek Preußischer Kulturbesitz, 15: 156-165.

Hammerschmidt, Ernst (1985), 'Wolfgang Voigt (1911-1982)', Zeitschrift der Deutschen Morgenländischen Gesellschaft, 135: 1-9. 
Kraatz, Martin (1987), 'Dieter George (1935-1985)', Zeitschrift der Deutschen Morgenländischen Gesellschaft, 137: 12-19.

Meyer, Wilhelm (ed) (1894), Verzeichniss der Handschriften im Preußischen Staate. I.3.3: Die Handschriften in Göttingen. Universitäts-Bibliothek: Nachlässe von Gelehrten; Orientalische Handschriften. Handschriften im Besitz von Instituten und Behörden. Register zu Band 1-3, Berlin: Bath.

Pertsch, Wilhelm (1878-92), Die arabischen Handschriften der Herzoglichen Bibliothek zu Gotha, 5 vols (Die Orientalischen Handschriften, 3-5), Gotha: Perthes.

Quiring-Zoche, Rosemarie (1989), 'Arabisches Schrifttum im Osmanischen Reich: Zur Handschriften-Sammlung Rescher', in Ewald Wagner and Klaus Röhrborn (eds), Kaškūl. Festschrift zum 25. Jahrestag der Wiederbegründung des Instituts für Orientalistik an der Justus-Liebig-Universität Gießen, Wiesbaden: Harrassowitz, 100-115.

Seidensticker, Tilman (2017), 'How Arabic Manuscripts Moved to German Libraries', manuscript cultures, 10: 73-82.

Sellheim, Rudolf (1974), 'The Cataloguing of Arabic Manuscripts as a Literary Problem', Oriens, 23/24: 306-311.

Verzeichnis der Orientalischen Handschriften in Deutschland, Wolfgang Voigt [then successively: Dieter George, Hartmut-Ortwin Feistel, Tilman Seidensticker] (eds) (1961-), Wiesbaden: Steiner.

Voigt, Wolfgang (1957/58), 'Anhang. Katalogisierung der orientalischen Handschriften in Deutschland', Westdeutsche Bibliothek. Jahresbericht 1957/58: 67-76.

Voigt, Wolfgang (ed) (1966), Forschungen und Fortschritte der Katalogisierung der Orientalischen Handschriften in Deutschland. Marburger Kolloquium 1965 (Deutsche Forschungsgemeinschaft, Forschungsberichte, 10), Wiesbaden: Steiner. 


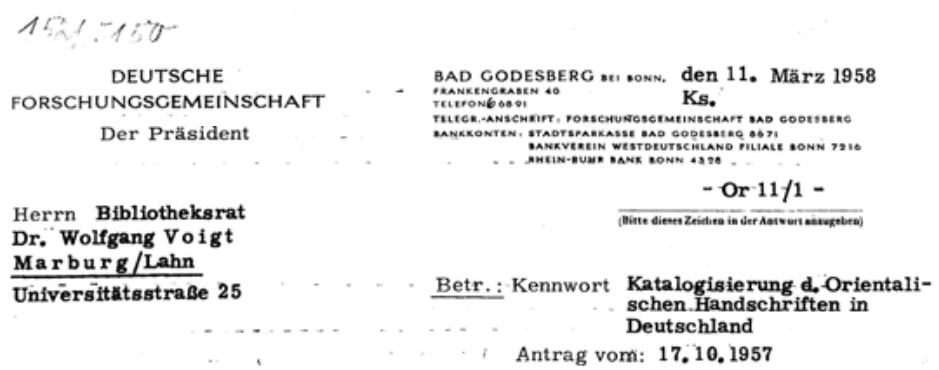

Sehr geehrter Herr Doktor!

Die Deutsche Forschungsgemeinschaft hat Ihnen eine

$$
\mathrm{S} \text { a c h b e i h i } 1 \text { f e }
$$

bewilligt, in deren Rahmen die erforderlichen Mittel zur Verfügung gestellt werden.

Für die Verwendung und Verrechnung der Sachbeihilfe gelten die beiliegenden Richtlinien mit der Maßgabe, daß the beschafften Apparate, Instrumente und wertvollem Materialien in das Eigentum des Bundes übergehen; sie werden als "Leihgabe der Deutschen Forschungsgemeinschaft" zur Verfügung gestellt.

Die Mittel sind bestimmt bis zur Höhe von

a) DM 78, 400, -- fur Personalausgaben ( 8 wiss. Mitarbeiter nach TOA III, jeweils auf ein Jahr, fröhestens ab 1.2.1958)

b) DM 12, 600, -- für Verbrauchsmaterial (Schreibarbeiten, Büromaterial, Katalogbec) DM 9, 000, -- für Reisekosten gem. Antrag.

Die Mittel zu a) und b) sind bis zu einem Betrag von DM 1.000, - gegenseitig deckungsfăhig.

Fenner 6ind -die-Mittel-zur Beachafiturg-cher von fhner erbetenen Apparate bewilingt worden:-

Der Innen bereits überbrückungsweise gezahlte Betrag von DM 3.000,-- wird auf diese Bewilligung angerechnet.

Sie sind verpflichtet, der Deutschen Forschungsgemeinschaft jährlich, erstmalig zum 1. Februar 1959 über den Fortgang Ihrer Arbeiten zu berichten. Von etwaigen Veröffentlichungen werden jeweils Sonderdrucke als Belegexemplare erbeten, die jedoch die Berichterstattung nicht ersetzen können.

Fig. 2: DFG grant letter, directed to Wolfgang Voigt; photocopy of the original document, contained in the file 'Schwerpunktaufgaben DFG. Handschriftenkatalogisierung. l', which is stored in the files of the KOHD project, Staatsbibliothek zu Berlin - Preußischer Kulturbesitz, Orientabteilung. (The personnel costs of 78,400 German marks amount to 9,800 German marks annually per person, which is surprisingly low. A year later, the sum of 15,034 German marks annually per person was calculated, due to improved pay scales; cf. Voigt's letter to the DFG, dated 21 Jan. 1959, same file.) 